

Jurnal Anugerah, 2(1) (2020)
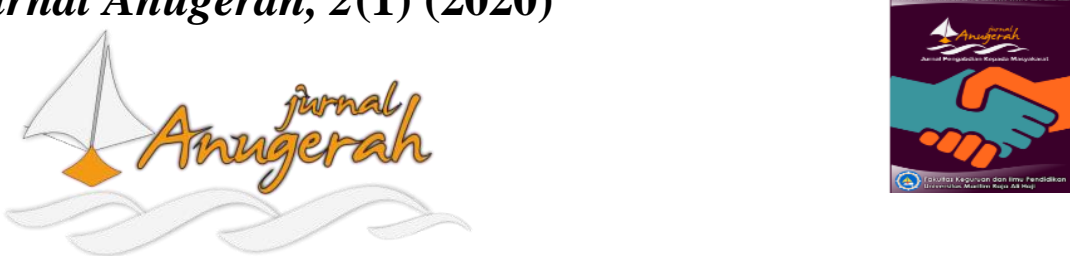

e-ISSN 2715-8179

https://ojs.umrah.ac.id/index.php/anugerah

\title{
Pembinaan Olimpiade Sains Nasional Bidang Matematika Topik Statistika dan Peluang Pada Siswa SMP Negeri 4 Tanjungpinang
}

\author{
Dios Sarkity $^{1^{*}}$, Mariyanti Elvi ${ }^{2}$, Metta Liana ${ }^{3}$, Dina Fitriyah ${ }^{4}$ \\ 1,2,3,4 Universitas Maritim Raja Ali Haji, Tanjungpinang, Kepulauan Riau 29115, Indonesia \\ *e-mail korespondensi: diossarkity@umrah.ac.id \\ Pengiriman: 6 Februari 2020; Diterima: 24 Mei 2020; Publikasi: 31 Mei 2020 \\ DOI: https://doi.org/10.31629/anugerah.v2i1.1977
}

\begin{abstract}
Abstrak
Olimpiade sains nasional (OSN) adalah suatu sarana untuk mengukur ketercapaian pembelajaran pada suatu mata pelajaran. Matematika merupakan salah satu bidang yang diujikan pada OSN. Banyak siswa menganggap matematika sebagai pelajaran yang sulit. SMPN 4 Tanjungpinang merupakan salah satu Sekolah Menengah Pertama di Tanjungpinang yang rutin mengirimkan utusan untuk mengikuti OSN tetapi masih kurang efektif dalam melakukan kegiatan pembinaan OSN. Oleh karena itu, diperlukan kegiatan berupa pembinaan terhadap Siswa yang akan mengikuti OSN bidang matematika. Kegiatan ini diselenggarakan di SMPN 4 Tanjungpinang dan diikuti oleh 10 Siswa yang berasal dari kelas VII dan kelas VIII. Kegiatan pembinaan dilaksanakan dalam dua pertemuan dengan menekankan pada penguatan konsep dan pelatihan penyelesaian soal-soal. Topik yang dibahas adalah statistika dan peluang. Tes berupa soal esai diberikan kepada peserta pembinaan untuk mengukur kemampuan siswa dalam memecahan masalah yang disajikan dalam soal olimpiade. Hasil tes menunjukkan bahwa siswa belum mampu untuk memecahkan masalah secara baik. Hal ini mengindikasikan pentingnya pembinaan yang lebih baik untuk memberikan penguatan konsep dan mengembangkan kemampuan siswa dalam memecahkan masalah olimpiade.
\end{abstract}

Kata kunci: pembinaan; olimpiade; matematika

\begin{abstract}
The National Science Olympiad (OSN) is a tool to measure learning achievement in a subject. Mathematics is one of the fields tested on OSN. Many students consider mathematics is a difficult subject. SMPN 4 Tanjungpinang is one of the junior high schools in Tanjungpinang that routinely sends delegates to attend OSN but is still less effective in conducting OSN training. Therefore, it was necessary to provide an activity in the form of training for students who will participate the OSN in mathematics. This activity was held at SMPN 4 Tanjungpinang and was attended by 10 students of class VII and class VIII. This Training activities carried out in two meetings with emphasis on strengthening concepts and training in problem solving. Topics covered were statistics and probabilities. Test results showed that students have not been able to solve the problems properly. This indicated the importance of better training to provide reinforcement of concepts and to develop students' abilities in solving olympiad problems.
\end{abstract}

Keywords: training; olympiad; mathematics 


\section{Pendahuluan}

Salah satu kompetisi sains tahunan untuk siswa menengah pertama adalah Olimpiade Sains Nasional (osn). Kegiatan OSN ini telah diselenggarakan sejak tahun 2003. Proses seleksi yang diterapkan pada OSN ini dilakukan secara bertahap mulai dari tingkat sekolah, kecamatan, kabupaten, provinsi hingga tingkat nasional. OSN merupakan sarana untuk mengaplikasikan kemampuan bidang sains yang telah didapatkan oleh siswa melalui pembelajaran dengan penguatan pendidikan karakter di sekolah (Kemendikbud, 2018a). Matematika merupakan salah satu bidang yang dilombakan pada OSN. Matematika dianggap bidang yang paling sulit yang dilombakan pada OSN karena pelajaran matematika itu sendiri dianggap sulit oleh siswa dan permasalahan yang disajikan di dalam soal matematika juga tidak mudah untuk diselesaikan (Fauzan \& Dzikrullah, 2018). Kesulitan siswa dalam menyelesaikan soal matematika ini umumnya meliputi kesulitan dalam memahami soal, kesulitan dalam menentukan dan menerapkan prosedur untuk menyelesaikan soal (Setiawan et al., 2018).

Berdasarkan silabus OSN bidang matematika tingkat Sekolah Menengah Pertama, di antara topik yang akan diujikan dalam OSN bidang matematika adalah statistika dan peluang (Kemendikbud, 2019a). Stastistika dan peluang merupakan materi yang harus diajarkan secara kontekstual untuk mendapatkan pemahaman konsep yang baik (Garfield \& Ahlgren, 1986). Beberapa hasil penelitian menunjukkan bahwa siswa masih mengalami kesulitan dalam materi peluang dan statistika. Siswa mengalami kesulitan dalam merepresentasikan dan mengindentifikasi permasalahan terkait peluang serta menentukan strategi yang tepat untuk menentukan peluang suatu kejadian (Ang \& Shahrill, 2014; Arum et al., 2018). Siswa juga tidak mampu membuat pemodelan untuk menentukan peluang dari suatu eksperimen acak (Gabriel, 2002). Selain itu, masih terdapat siswa yang menganggap bahwa besar peluang suatu kejadian tidak bisa ditentukan secara matematis (Anggraini \& Kusrini, 2018). Pada konsep statistik, hasil penelitian menunjukkan adanya kesulitan siswa dalam menentukan ukuran tendensi sentral (Ismail \& Chan, 2015; Tirangkoor et al., 2018). Siswa juga mengganggap bahwa rata-rata setara dengan standar deviasi sehingga kenaikan nilai rata-rata juga akan menyebabkan kenaikan nilai standar deviasi (Chan \& Ismail, 2013).

Soal olimpiade matematika identik dengan soal pemecahan masalah. Pada pemecahan masalah matematika, siswa harus dapat memahami masalah yang diberikan (understanding the problem), menentukan strategi pemecahan masalah (devising a plan), melaksanakan tahap-tahap pemecahan masalah berdasarkan strategi yang ditentukan (Carrying out the plan), hingga mengevaluasi proses pemecahan masalah yang dilakukan (looking back) (Polya, 1945). Ketidakmampuan siswa dalam menyelesaikan masalah matematika bukan hanya karena kurangnya kemampuan matematis tetapi juga kurangnya pemahaman konsep (Tambychik \& Meerah, 2010). Siswa akan mampu memecahkan berbagai masalah jika kemampuan siswa didukung oleh pemahaman konsep yang baik (Garrett, 1986; Mason \& Singh, 2016). Kesulitan siswa dalam memahami konsep menyebabkan berbagai kendala dalam proses pemecahan masalah (Docktor et al., 2015). Kesulitan ini dialami oleh siswa pada segala tingkat termasuk siswa pada tingkat Sekolah Menengah Pertama (SMP).

SMP Negeri 4 merupakan salah satu Sekolah Menengah Pertama di Kota Tanjungpinang yang rutin dalam mengirimkan siswanya untuk mengikuti seleksi OSN Matematika. Berdasarkan data-data peserta OSN matematika yang mewakili Provinsi Kepulauan Riau selama 5 tahun terakhir seperti yang ditunjukkan oleh tabel 1, tidak ada satupun peserta yang berasal dari SMPN 4 Tanjungpinang. Berdasarkan hasil observasi dan wawancara terhadap pihak sekolah, pembinaan olimpiade yang dilaksanakan di SMP Negeri 4 Tanjungpinang masih kurang efektif. Ketidakefektifan ini dilihat dari tidak rutinnya pelaksanaan kegiatan pembinaan terhadap siswa yang mengikuti OSN. Seringkali siswa yang akan diikutsertakan dalam kegiatan OSN Matematika dipersiapkan dan dibina menjelang pelaksanaan kegiatan OSN. 
Sarkity, dkk: Pembinaan Olimpiade Sains Nasional... (4)

Tabel 1

Nama Peserta OSN bidang Matematika Perwakilan Provinsi Kepulauan Riau 5 Tahun Terakhir (Kemendikbud, 2015; Kemendikbud, 2016; Kemendikbud, 2017; Kemendikbud, 2018a; Kemendikbud, 2019a)

\begin{tabular}{|c|c|c|c|c|}
\hline Tahun & No & Nama Peserta & Asal Sekolah & Kab/Kota \\
\hline \multirow[t]{2}{*}{2015} & 1 & Tiara Pusita Ayuni & SMPS Tabqha & Kota Batam \\
\hline & 2 & Vincent & SMPS Maitreyawira Batam & Kota Batam \\
\hline \multirow[t]{2}{*}{2016} & 1 & Muhammad Hilmy Fauzi & SMP Islam Terpadu Imam Syafi'i & Kota Batam \\
\hline & 2 & Gilbert Ng & SMPS Bodhi Dharma Batam & Kota Batam \\
\hline \multirow[t]{2}{*}{2017} & 1 & Lawrance Carncerlon & SMPN 5 Tanjungpinang & Kota Tanjungpinang \\
\hline & 2 & Charles & SMPS Maitreyawira Tanjungpinang & Kota Tanjungpinang \\
\hline \multirow[t]{3}{*}{2018} & 1 & Vincent Rocky & SMPN 5 Tanjungpinang & Kota Tanjungpinang \\
\hline & & Simanjuntak & & \\
\hline & 2 & Jeffrey & SMP Maha Bodhi & Kab. Karimun \\
\hline \multirow[t]{5}{*}{2019} & 1 & Vincent Rocky & SMPN 5 Tanjungpinang & Kota Tanjungpinang \\
\hline & & Simanjuntak & & \\
\hline & 2 & Justin & SMP Mondial & Kota Batam \\
\hline & 3 & Melisa Lee & SMPN 6 Batam & Kota Batam \\
\hline & 4 & Tita Larasati Tjoa & SMP Monte Sienna & Kota Batam \\
\hline
\end{tabular}

Pembinaan Olimpiade merupakan salah satu solusi untuk mempersiapkan siswa dalam mengikuti olimpiade sains nasional. Pembinaan olimpiade dapat memberikan siswa suatu pemahaman konsep yang baik serta pengetahuan tentang bagaimana menyelesaikan soal-soal dengan tepat (Siregar, 2017). Pemberian pembinaan olimpiade tidak hanya memberikan siswa pengetahuan tetapi juga meningkatkan antusias siswa dalam mengikuti olimpiade sehingga siswa tidak hanya siap secara pengetahuan tetapi juga secara mental (Gita, Suryawan, \& Artawan, 2017). Selain untuk mempersiapkan siswa dalam mengikuti olimpiade sains nasional, pembinaan olimpiade juga mempersiapkan siswa dalam mengikuti materi pembelajaran di kelas karena materi olimpiade sejalan dengan materi yang diajarkan di kelas (Fauzan \& Dzikrullah, 2018)

Berdasarkan pemaparan masalah di atas, maka Tim Pengabdian Kepada Masyarakat (PKM) Universitas Maritim Raja Ali Haji (UMRAH) melakukan kegiatan pembinaan pra-Olimpiade Sains Nasional (OSN) bidang matematika di SMP Negeri 4 Tanjungpinang. Kegiatan ini bertujuan untuk melakukan pembinaan terhadap siswa yang akan diikutsertakan dalam kegiatan OSN bidang matematika.

\section{Metode}

Kegiatan ini dilaksanakan dengan cara melakukan pembinaan. Kegiatan pembinaan ini terdiri atas penguatan konsep dengan merujuk pada kisi-kisi Olimpiade Sains Nasional Matematika serta pelatihan penyelesaian soal-soal olimpiade matematika berdasarkan konsep yang dipelajari. Soal-soal yang diberikan 
saat pembinaan didominasi oleh soal-soal olimpiade yang pernah diujikan pada tahun-tahun sebelumnya yang telah dikelompokkan berdasarkan materi. Kegiatan pembinaan diikuti oleh 10 orang siswa SMP Negeri 4 Tanjungpinang yang merupakan siswa yang berasal dari kelas VII dan VIII. Kegiatan pembinaan dilakukan selama 2 kali pertemuan di mana setiap pertemuan dilakukan penguatan konsep dan pembahasan soal-soal pada topik yang berbeda-beda.

Agar dapat mengukur keberhasilan kegiatan pembinaan yang dilakukan, TIM PKM UMRAH memberikan tes dengan menggunakan soal esai untuk mengukur kemampuan siswa dalam menyelesaikan masalah pada soal olimpiade pada materi statistika dan peluang. Soal-soal yang digunakan adalah soal yang dibuat oleh Tim PKM UMRAH dengan mengadaptasi soal-soal yang pernah diujikan pada OSN bidang matematika serta telah dibahas saat kegiatan pembinaan. Jawaban siswa dianalisis dengan menggunakan rubrik analisis pemecahan masalah seperti yang ditunjukkan pada tabel 2.

Tabel 2

Rubrik Analisis Pemecahan Masalah (Randall et al., 1987)

\begin{tabular}{lcll}
\hline Komponen Analisis & Skor & & \multicolumn{1}{c}{ Keterangan } \\
\hline Understanding & The & 2 & Memahami masalah secara lengkap \\
Problem & 1 & Sebagian masalah dipahami atau diinterpretasikan secara tidak tepat \\
& 0 & Keseluruhan masalah dipahami secara tidak tepat \\
Planning a Solution & 2 & Strategi dapat menghasilkan solusi yang benar jika diimplementasikan \\
& & secara tepat \\
& 1 & Sebagian strategi yang dibuat berdasaksarkan masalah yang disajikan \\
& & diintrepretasikan secara tepat \\
& & Tidak ada strategi pemecahan masalah atau strategi yang digunakan tidak \\
& & tepat sama sekali untuk menghasilkan solusi \\
Getting an Answer & 2 & Jawaban benar \\
& 1 & Sebagian proses menemukan solusi benar. \\
& 0 & Jawaban salah karena menerapkan strategi yang salah. \\
& &
\end{tabular}

Siswa yang dikatakan berhasil dalam memecahkan masalah pada soal olimpiade adalah siswa yang memperoleh skor 2 di setiap komponennya. Keberhasilan siswa dalam menyelesaikan masalah pada soal olimpiade mengindikasikan keberhasilakan pelaksanaan kegiatan pembinaan.

\section{Hasil dan Pembahasan}

Kegiatan pengabdian kepada masyarakat dalam bentuk pembinaan pra-OSN pada siswa SMP Negeri 4 Tanjungpinang ini dilaksanakan pada November 2019. Pada pelaksanaannya, kegiatan pembinaan praOlimpiade Sains Nasional bidang matematika ini dilakukan dalam 2 kali pertemuan. Kegiatan pembinaan 
dilakukan selama 90 menit di setiap pertemuannya. Pada setiap pertemuan, 30 menit pertama siswa diberikan penguatan konsep berdasarkan topik yang akan dibahas. Setelah diberikan penguatan konsep, 60 menit berikutnya siswa diberikan pelatihan penyelesaian soal-soal dengan menggunakan konsep yang telah diberikan.

Topik yang dibahas dalam pembinaan praolimpiade sains nasional bidang matematika ini adalah statistika dan peluang. Pemilihan topik statistika dan peluang ini dilakukan berdasarkan kisi-kisi olimpiade Sains Nasional bidang matematika pada tingkat SMP. Statistika dan peluang merupakan materi yang diajarkan pada kelas IX SMP sedangkan peserta pembinaan praolimpiade berasal dari kelas VII dan kelas VIII. Oleh karena itulah, penguatan konsep diberikan secara mendetail mengingat para peserta pembinaan belum mempelajari materi tersebut di kelas. Pembinaan untuk topik statistika dan peluang masing-masing dilakukan dalam satu pertemuan yaitu pada tanggal 16 Nopember 2019 untuk materi statistika dan pada tanggal 23 Nopember 2019 untuk materi peluang.

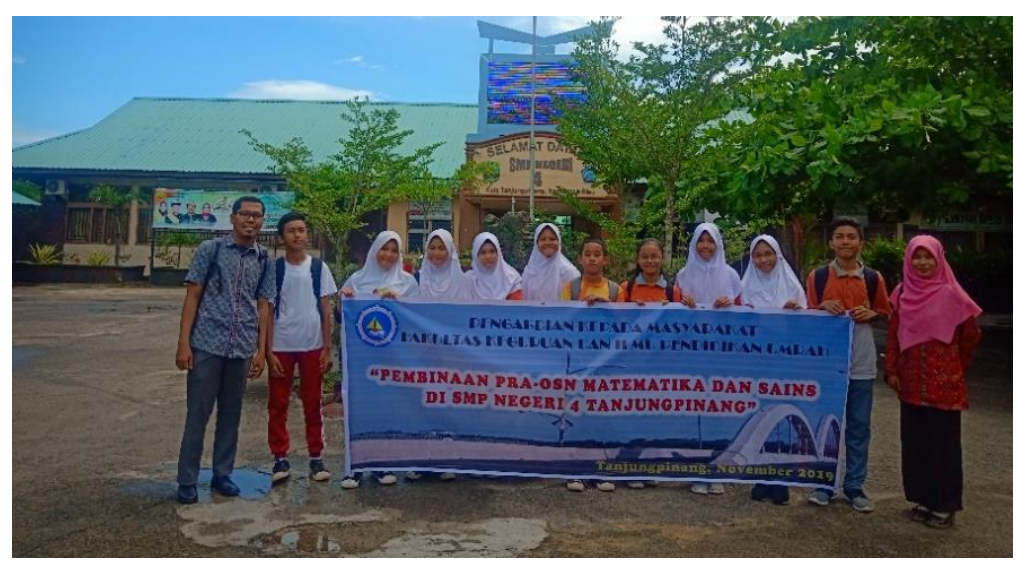

Gambar 1. Dosen Pembina pra-OSN Matematika dan Siswa Peserta Pembinaan

Agar dapat mengukur keberhasilan kegiatan pembinaan olimpiade yang dilakukan, tim pengabdian memberikan tes dengan menggunakan soal esai. Soal tes yang digunakan diadaptasi dari soal-soal olimpiade yang pernah diujikan. Pada soal tes statistika dan peluang, masing-masing berjumlah satu soal seperti yang ditunjukkan pada gambar 2 .

\section{STATISTIKA}

1. 5 bilangan positif berbeda yang sudah diurutkan dilambangkan dengan $x_{1}, x_{2}, x_{3}, x_{4}$, dan $x_{5}$. Jika jangkauan data adalah $10, x_{1}=\frac{1}{3}$ Median, Median $=\frac{1}{2} x_{5}$, dan jumlah 3 bilangan pertama sama dengan setengah dari jumlah dua bilangan terakhir, maka rata-rata kelima bilangan tersebut adalah ...

PELUANG

2. Dua buah dadu dan sekeping uang logam dilempar sekaligus. Peluang untuk mendapatkan gambar pada sisi mata uang dan jumlah mata kedua dadu merupakan bilangan prima adalah ...

Gambar 2. Soal Tes Pemecahan Masalah Statistika dan Peluang

Berdasarkan hasil tes yang dilakukan, ditemukan bahwa rata-rata siswa belum bisa memecahkan masalah secara baik seperti yang ditunjukkan oleh rekaptulasi pemecahan masalah siswa pada tabel 1 . Kebanyakan siswa tidak bisa memahami masalah secara baik sehingga siswa kesulitan tidak menggambakan masalah secara tepat untuk memecahkan masalah. Kebanyakan siswa juga tidak bisa menentukan strategi yang tepat untuk menemukan solusi masalah. Penerapan strategi yang tidak tepat untuk memecahkan 
JURNAL ANUGERAH, Mei 2020; 2(1): 27 - 36

e-ISSN. 2715-8179

masalah ini menyebabkan siswa melakukan kesalahan dalam menerapkan proses matematika untuk menemukan solusi masalah.

Tabel 3

Rekaptulasi Hasil Pemecahan Masalah Pada Topik Peluang dan Statistika

\section{Topik}

\begin{tabular}{|c|c|c|c|c|c|c|}
\hline \multirow{3}{*}{ Siswa } & \multicolumn{3}{|c|}{ Statistika } & \multicolumn{3}{|c|}{ Peluang } \\
\hline & Understanding & Planning & Getting the & Understanding & Planning $a$ & Getting the \\
\hline & the problem & a solution & answer & the problem & solution & answer \\
\hline 1 & 1 & 0 & 0 & 1 & 1 & 1 \\
\hline 2 & 1 & 0 & 0 & 1 & 0 & 0 \\
\hline 3 & 0 & 0 & 0 & 0 & 0 & 0 \\
\hline 4 & 1 & 0 & 0 & 1 & 1 & 1 \\
\hline 5 & 1 & 0 & 0 & 1 & 0 & 0 \\
\hline 6 & 0 & 0 & 0 & 0 & 0 & 0 \\
\hline 7 & 2 & 2 & 1 & 1 & 1 & 1 \\
\hline 8 & 1 & 1 & 1 & 1 & 1 & 1 \\
\hline 9 & 1 & 1 & 1 & 0 & 0 & 0 \\
\hline 10 & 2 & 1 & 1 & 1 & 1 & 1 \\
\hline
\end{tabular}

Berdasarkan hasil pemecahan masalah Statistika, hampir keseluruhan peserta pembinaan belum bisa memahami masalah secara tepat. Kebanyakan kesalahan terjadi pada penentuan nilai $\mathrm{X}_{3}$ sebagai median serta menggambarkan hubungan antara $\mathrm{X}_{1}$ dan $\mathrm{X}_{5}$ berdasarkan nilai jangkauan yang diberikan. Kesalahan dalam penggambaran awal kondisi masalah menyebabkan kebanyakan siswa juga salah dalam menentukan strategi pemecahan masalah. Kesalahan menentukan strategi pemecahan masalah juga menyebabkan siswa melakukan proses matematis yang salah dalam menemukan solusi masalah (Setiawan et al., 2018). 


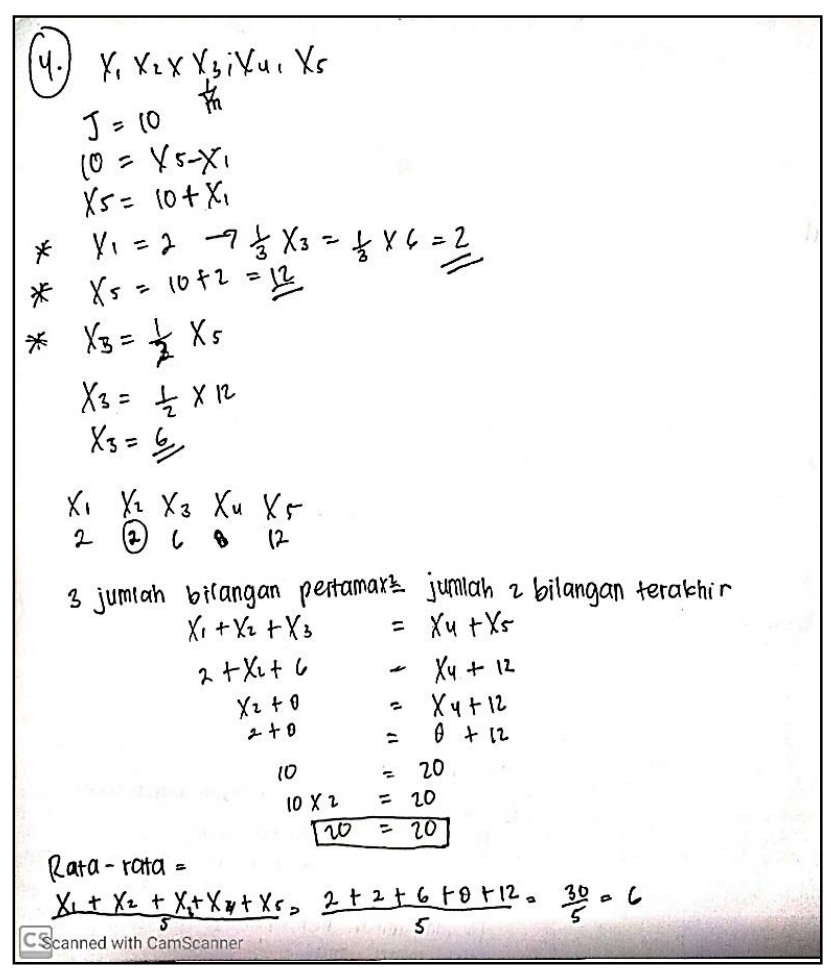

Gambar 3. Hasil Pemecahan Masalah Statistika

Hasil pemecahan masalah statistika terbaik ditunjukkan oleh hasil pemecahan masalah siswa 7 yang ditunjukkan pada gambar 3. Pada hasil tersebut dapat dilihat bahwa siswa mampu menggambarkan kondisi masalah secara baik, hal ini dapat dilihat dari hubungan antara $\mathrm{X}_{1}, \mathrm{X}_{3}$ dan $\mathrm{X}_{5}$ yang digambarkan secara tepat. Pada proses pemecahan masalah siswa juga mampu menggunakan konsep yang tepat untuk menemukan solusi masalah, hal ini dilihat dari pemilihan strategi yang digunakan untuk menemukan solusi masalah. Tetapi, solusi akhir yang diberikan oleh siswa kurang tepat di mana siswa tidak memperhatikan secara saksama bahwa lima bilangan bulat positif yang dimaksudkan pada soal adalah lima bilangan yang berbeda. Pada jawaban siswa 7 dapat dilihat bahwa siswa melakukan pengulangan pada nilai $\mathrm{X}_{1}$ dan $\mathrm{X}_{2}$. Berdasarkan dari hasil pemecahan masalah yang dilakukan oleh siswa 7 ini dapat disimpulkan bahwa siswa tersebut mampu memahami masalah secara tepat dan menentukan strategi yang tepat untuk menemukan solusi masalah jika diimplementasikan secara tepat. Namun, siswa melakukan kesalahan dalam proses matematis untuk menemukan solusi masalah sehingga menyebabkan siswa 7 mendapatkan skor 2 untuk understanding the problem, skor 2 untuk planning a solution, dan skor 2 untuk getting the answer.

Hasil yang tidak jauh berbeda ditunjukkan oleh hasil pemecahan masalah peluang. Tidak ada satu pun siswa yang memberikan solusi pemecahan secara tepat. Kesalahan dimulai dari penggambaran masalah yang diberikan sehingga siswa tidak dapat menentukan banyak ruang sampel serta banyak kejadian dari pelemparan dua buah dadu beserta satu koin. Kesalahan dalam penggambaran awal berdampak pada pemilihan strategi pemecahan masalah sehingga siswa tidak bisa menemukan solusi pemecahan masalah secara tepat. Kesalahan dalam proses pemecahan masalah ini dapat dilihat pada hasil pemecahan masalah siswa 10 seperti yang ditunjukkan pada gambar 4. Pada gambar 4 dapat dilihat bahwa siswa memisahkan antara kejadian pelemparan dua buah dadu dan pelemparan satu buah koin, di mana seharusnya kedua kejadian tersebut digabung untuk menentukan ruang sampel dan banyaknya kejadiannya. Selain itu siswa juga masih kurang tepat dalam menentukan pasangan dua buah dadu bermata bilangan prima. Kesalahan ini menyebabkan siswa menghasilkan nilai peluangan yang tidak tepat. Berdasarkan jawaban siswa 10 ini, maka siswa mendapatkan skor 1 untuk understanding the problem, skor 1 untuk planning a solution, dan skor 1 untuk getting the answer. 


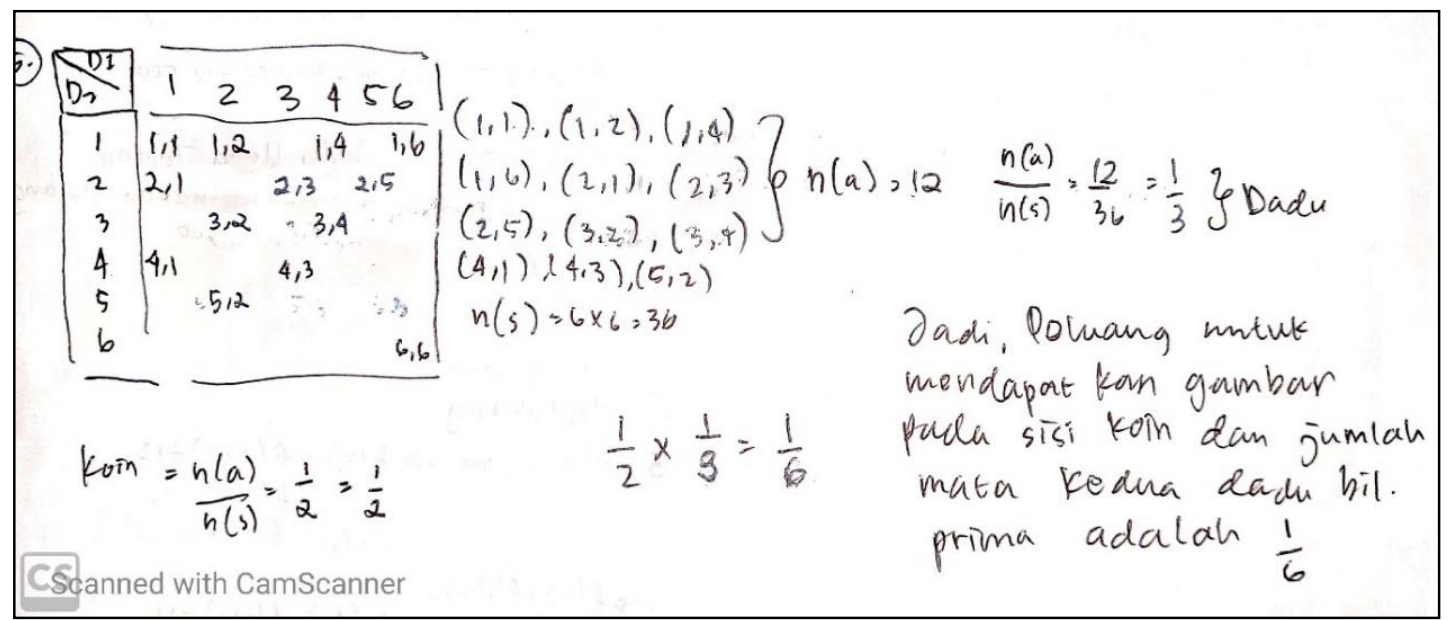

Gambar 4. Hasil Pemecahan Masalah Peluang

Berdasarkan hasil tes yang dilakukan, dapat dilihat bahwa masih terdapat kesulitan pada siswa dalam memecahkan masalah statistika dan peluang. Melalui permasalahan statistika yang disajikan pada tes, siswa belum mampu memecahkan masalah yang berhubungan dengan konsep ukuran tendensi sentral secara baik seperti yang ditemukan oleh Islamil \& Chan (2015) dan Tirangkoor et al (2018). Berdasarkan permasalahan peluang yang disajikan pada tes, dapat dilihat bahwa siswa belum mampu membuat pemodelan masalah peluang secara tepat seperti yang ditemukan pada hasil penelitian Gabriel (2002). Kesulitan siswa dalam menentukan pemodelan awal masalah peluang akan berdampak pada penentuan strategi untuk menentukan peluang suatu kejadian (Ang \& Shahrill, 2014; Arum et al., 2018). Hal ini mengindikasikan perlunya pemahaman konsep yang lebih baik karena pemahaman konsep yang tidak tepat menyebabkan kesalahan dalam proses pemecahan masalah (Arum et al., 2018; Docktor et al., 2015; Konold, 1995).

\section{Kesimpulan}

Hasil pembinaan pra-Olimpiade Sains Nasional bidang matematika yang dilaksanakan di SMP Negeri 4 Tanjungpinang, dapat dilihat melalui hasil pemecahan masalah siswa melalui tes yang diberikan setelah kegiatan pembinaan dilaksanakan. Berdasarkan hasil tes yang dilakukan dapat dilihat bahwa siswa belum mampu menyelesaikan masalah yang disajikan pada soal olimpiade secara baik, baik pada materi statistika maupun peluang. Berdasarkan hasil tes yang dilakukan, siswa belum bisa memahami masalah secara baik akibatnya siswa yang tidak bisa menentukan strategi yang tepat untuk menemukan solusi masalah secara tepat. Pemilihan strategi yang kurang tepat untuk menentukan solusi masalah ini menyebabkan siswa tidak dapat menghasilkan solusi masalah secara tepat. Hasil tes pemecahan masalah ini mengindikasikan bahwa kegiatan pembinaan pra-OSN bidang matematika pada siswa SMPN 4 Tanjungpinang pada topik statistika dan peluang belum berhasil untuk mengembangkan kemampuan siswa dalam memecahkan masalah yang disajikan dalam soal olimpiade matematika khususnya pada materi statistika dan peluang.

\section{Saran}

Berdasarkan hasil kegiatan pengabdian masyarakat yang dilakukan dalam bentuk pembinaan praOlimpiade Sains Nasional (OSN) di SMP Negeri 4 Tanjungpinang, tim pengabdian kepada masyarakat memberikan saran sebagai berikut:

1. Pembinaan olimpiade harus menekankan pada penguatan konsep.

2. Melalui kegiatan pembinaan, siswa harus dilatih untuk terbiasa menyelesaikan soal-soal pemecahan masalah seperti pada soal-soal olimpiade sehingga kegiatan pembinaan dapat mengembangkan 
kemampuan siswa dalam memahami permasalahan, menentukan strategi untuk menyelesaikan masalah, serta mengimplementasikan strategi pemecahan masalah untuk menemukan solusi soal.

3. Kegiatan pembinaan akan menghasilkan hasil yang lebih baik jika dilaksanakan secara rutin sehingga pembinaan terhadap suatu materi bisa dilakukan dalam beberapa kali pertemuan.

\section{Ucapan Terima Kasih}

Tim pengabdian mengucapkan terima kasih banyak kepada LP3M UMRAH yang telah memberikan dukungan demi terlaksananya kegiatan pengabdian kepada masyarakat ini. Tidak lupa pula tim pengabdian mengucapkan terima kasih banyak kepada pihak SMP Negeri 4 Tanjungpinang yang telah bersedia menjadi mitra serta memfasilitasi kegiatan pengabdian kepada masyarakat ini.

\section{Referensi}

Ang, L. H., \& Shahrill, M. (2014). Identifying students' specific misconceptions in learning probability. International Journal of Probability and Statistics, 3(2), 23-29. https://doi.org/10.5923/j.ijps.20140302.01

Anggraini, S., \& Kusrini, E. (2018). The analysis of students' difficulties in solving problems of probability for 8th grade. 160(Incomed 2017), 166-169. https://doi.org/10.2991/incomed-17.2018.36

Arum, D. P., Kusmayadi, T. A., \& Pramudya, I. (2018). Students' difficulties in probabilistic problemsolving. Journal of Physics: Conference Series, 983(1). https://doi.org/10.1088/17426596/983/1/012098

Chan, S. W., \& Ismail, Z. (2013). Assessing misconceptions in reasoning about variability among high school students. Procedia - Social and Behavioral Sciences, 93, 1478-1483. https://doi.org/10.1016/j.sbspro.2013.10.067

Docktor, J. L., Strand, N. E., Mestre, J. P., \& Ross, B. H. (2015). Conceptual problem solving in high school physics. Physical Review Special Topics - Physics Education Research, 11(2), 1-13. https://doi.org/10.1103/PhysRevSTPER.11.020106

Fauzan, A., \& Dzikrullah, A. A. (2018). Optimalisasi kecerdasan siswa dengan intensitas pembinaan olimpiade matematika. Jurnal Matemtatika, Statistika, \& Komputasi, 6(2), 86-91.

Gabriel, Y. (2002). Students' difficulties and strategies in solving conditional probability problems with computational simulation. Journal of Chemical Information and Modeling, 53(9), 1689-1699. https://doi.org/10.1017/CBO9781107415324.004

Garfield, J., \& Ahlgren, A. (1986). Difficulties in learning probability and statistics. Proceedings of the Second International Conference on Teaching Statistics, 270-274. papers3://publication/uuid/80EB4AA9-4353-4CFA-BD3F-88B6A29D69E2

Garrett, R. M. (1986). Problem-solving in science education. Studies in Science Education, 13(1), 70-95. https://doi.org/10.1080/03057268608559931

Ismail, Z., \& Chan, S. W. (2015). Malaysian students' misconceptions about measures of central tendency: An error analysis. AIP Conference Proceedings, 1643(February), 93-100. https://doi.org/10.1063/1.4907430

Kemendikbud. (2015). Surat Keputusan Direktur Pembinaan Sekolah Menengah Pertama Direktoral Jenderal Pendidikan Dasar Kementerian Pendidikan dan Kebudayaan Tahun 2015 Nomor. 799/C3/KU/2015. Kemendikbud: Jakarta.

Kemendikbud. (2016). Surat Keputusan Direktur Pembinaan Sekolah Menengah Pertama Direktoral Jenderal Pendidikan Dasar Kementerian Pendidikan dan Kebudayaan Tahun 2016 Nomor. 1022/D3/KP/2016. Kemendikbud: Jakarta.

Kemendikbud. (2017). Surat Keputusan Direktur Pembinaan Sekolah Menengah Pertama Direktoral Jenderal Pendidikan Dasar Kementerian Pendidikan dan Kebudayaan Tahun 2017 Nomor. 1273/D3/KP/2017. Kemendikbud: Jakarta.

Kemendikbud. (2018a). Panduan Pelaksanaan Olimpiade Sains Nasional Tahun 2018.

Kemendikbud. (2018b). Surat Keputusan Direktur Pembinaan Sekolah Menengah Pertama Direktoral Jenderal Pendidikan Dasar Kementerian Pendidikan dan Kebudayaan Tahun 2018 Nomor. 1677/D3/KP/2018. Kemendikbud: Jakarta.

Kemendikbud. (2019a). Silabus Olimpiade Sains Nasional (OSN) Sekolah Menengah Pertama.

Kemendikbud. (2019b). Surat Keputusan Direktur Pembinaan Sekolah Menengah Pertama Direktoral 
Jenderal Pendidikan Dasar Kementerian Pendidikan dan Kebudayaan Tahun 2019 Nomor. 1535/D3/KP/2019. Kemendikbud: Jakarta.

Konold, C. (1995). Issues in assessing conceptual understanding in probability and statistics. Journal of Statistics Education, 3(1). https://doi.org/10.1080/10691898.1995.11910479

Mason, A., \& Singh, C. (2016). Using categorization of problems as an instructional tool to help introductory students learn physics. Physics Education, 5l(2), 1-5. https://doi.org/10.1088/00319120/51/2/025009

Polya, G. (1945). Reviewed work: how to solve it by G. Pólya. In The Mathematical Gazette, 30, 181. https://doi.org/10.2307/3609122

Randall, C., Lester, F., \& O'Daffer, P. (1987). How to evaluate progress in problem-solving. National Council of Teachers of Mathematics.

Setiawan, Y. B., Hapizah, H., \& Hiltrimartin, C. (2018). Kesalahan siswa dalam menyelesaikan soal olimpiade Sekolah Menengah Pertama. Konten Aljabar. 5(2), 233-243. https://doi.org/http://doi.org/10.21831/jrpm.v5i2.18191

Tambychik, T., \& Meerah, T. S. M. (2010). Students' difficulties in mathematics problem-solving: What do they say? Procedia - Social and Behavioral Sciences, 8(5), 142-151. https://doi.org/10.1016/j.sbspro.2010.12.020

Tirangkoor, S., Chaiyasang, S., \& Kaewsaiha, C. (2018). Teaching strategies to correct misconceptions in descriptive statistics. Proceedings of 122nd The IRES International Conference, 57-61. 